\title{
Bekim Fehmiu and (Yugoslav) Albanian Identity
}

\author{
By Bruce Williams
}

Spring 2007 Issue of KINEMA

\section{DOUBLE EAGLE, DOUBLE INDEMNITY: BEKIM FEHMIU AND (YUGOSLAV) ALBA- NIAN IDENTITY}

"ONCE upon a time there was a country, and its capital was Belgrade." These opening words of Kusturica's Underground (1995) allow us to reflect on the apparent unity forged by Tito in Yugoslavia and the notion, however fleeting, of Yugoslav cinema. As Dina Iordanova asserts, this statement at once foregrounds Kusturica's claim that Yugoslav union had been "an artificial political construction built on lies and mutual betrayal" (Iordanova 2002, 83), and evokes an undeniable nostalgia for the defunct state. In wake of the bombardment of Dubrovnik, the wars in Bosnia and Kosovo, and unrest in Macedonia, we recall with certain fondness an era in which Yugoslavia provided a peaceful and accessible portal between East and West.

The ambivalence of Kusturica's stance recalls Edward Said's reconsideration of the relationship of divergent communities to the ever-fluctuating nation-state, an argument which has provided a theoretical framework for recent re-figurations of the notion of national cinema by such critics as Mette Hjort, Scott Mackensie, Andrew Higson, and Ian Jarvie. These new scholarly debates have explored national cinema from the loci of production, reception (both local and international), and critical assessment. Iordanova's seminal study, Cinema of Flames: Balkan Film, Culture and the Media, pluralizes the turf of the national, and examines the phenomenon of national cinematic voice in the context of the complex cultural entity known as the Balkans, which she argues is widely defined by "shared Byzantine, Ottoman and Austro-Hungarian legacies and by the specific marginal positioning of the region in relation to the western part of the European continent" $(2001,6)$.

Reminding us of Žižek's assertion that determining the confines of the Balkans would require measuring the imaginary, Iordanova seeks an expanded definition of the Balkans to embrace Turkey and Greece (7). Yet despite her excellent and ground-breaking analysis, one voice is all but silenced in Iordanova's work, that of a country half again the size of New Jersey, which borders the former Yugoslavia and whose virtual isolation from the rest of the world for some forty-five years rendered its cinema the most inaccessible of all Balkan nations. Albania, "the land of the (double) eagle," has held great fascination for the West from the poetic musings of Lord Byron to the early twentieth-century ethnographic writings of Edith Durham and Rose Wilder Lane. Yet, as seen by Kosovo ${ }^{(1)}$ and Macedonia, the notion of Albanian nationhood is not confined to the borders of the small nation-state. The world now notes the Albanian population of the former Yugoslavia. The Albanian issue was very much alive under Tito, and has come to the forefront following the country's splintering. This complexity of a hyphenated Albanian-Yugoslav identity is embodied by the career and persona of actor Bekim Fehmiu.

Critical assessments of the phenomenon of national identity have indeed engendered much debate, particularly in what concerns nationhood as performance and the concurrent notion of a spectatorship of the national. Nationhood can be read from divergent points from within and from outside of the culture. National identity is a negotiated meaning, and it is closely tied to shifting sites of reception. If nationhood is "performed," then it is by extension received by spectators. The "national" as posited by members of an inside group may differ markedly from the perception of outsiders, who attribute to a given nation a distinct set of traits and denominators not owned by its members. The reception of the national is divergent and unstable, sometimes allowing or rejecting the very existence of a given nation. A group may perceive itself to be a distinct nation, yet from the outside, it is subsumed into the surrounding national discourses. Hence, it struggles to assert its own identity in an environment that would squelch its self-perceived uniqueness. Conversely, a nation may be "invented," to countless ends, by outsiders who are more invested in its uniqueness than its own alleged members. And what better site for such dynamics than the former Yugoslavia, where a dialectic between perceived unity and asserted difference has been the order of many a day.

Fehmiu's career was among the most international of any Yugoslav film star, and together with occasional appearances in US and British film, he worked most extensively in Italy. He is most known to US audiences as 
the Yugoslav male sex symbol exported in 1970 to star in Lewis Gilbert's The Adventurers, a well-publicized bomb based on the novel by Harold Robbins for which, as Vincent Canby asserts, the "film rights had been sold even before Robbins had begun to dictate it." Cast as an international playboy closely modelled on Porfirio Rubirosa, Fehmiu's presence in The Adventurers "embalkanizes" Latin America and speaks to the commonalities of struggles in divergent parts of the world. Set in a fictitious country called Corteguay, whose history draws upon that of the Dominican Republic, yet is vague enough to serve as an amalgam of all of Latin America, The Adventurers promised more than it could deliver.

Touted on the cover of the US video release by Paramount as a "tale of the insatiable quest for revenge....and the good life," the film features Candice Bergen, Olivia de Havilland, Ernest Borgnine, Rossano Brazzi, Charles Aznavour, Leigh Taylor-Young, and Anna Moffo, whose nude scenes marked the waning of an international operatic career. And leading the cast was a Yugoslav - and an ethnic Albanian to boot! Yet for the West, Fehmiu was simply Yugoslav. While the extensive press coverage of The Adventurers in Yugoslavia spoke of his Albanian ethnicity, the US press referred to him as Yugoslav.

By the end of the 1980s, Fehmiu had virtually retired from both the stage and the cinema, citing the demoralizing anti-Albanian propaganda as the impetus for this decision. The actor, who had received both training in Belgrade's Academy of Dramatic Arts and nurturing in the Yugoslav National Theatre, was indeed invested in both sides of the ethnic conflict. The concept of nationality is problematized in his case and appears to be closely related to reception in diverse parts of the world and during different time periods. This discussion, although referencing numerous moments in Fehmiu's career, will focus primarily on the late sixties and early seventies, the period extending from the extensive press coverage on the release of The Adventurers to Fehmiu's 1972 visit to Albania.

\section{Son of Sarajevo?}

Some words are in order regarding Fehmiu's biography, particularly inasmuch as the accounts thereof are not without contradiction and ambiguity. Known primarily as a Kosovar Albanian, Fehmiu was decidedly born outside of Kosovo. Yet, where? The most common assertion is that he was born in 1936 in Sarajevo, to an ethnic Albanian family, which subsequently moved to Shkodër, Albania for several years, prior to settling in Kosovo. This account is corroborated by the actor's 1999 Serbian-language autobiography, Brilliant and Terrifying (Blistavo i straško), which focuses on Fehmiu's family life and education. Yet both the date and place of birth are contested. A reference in the Serbian press from the time of the filming of The Adventurers, for example, quotes Fehmiu as claiming to have been born in Kukës, Albania, a town near the border with Kosovo which would make headlines a little over sixty years later during the recent war as a crossing point for refugees ("Bekim kao Rubiroza" 9). One could simply attribute the account of Fehmiu's Albanian birth to sloppy journalism, but an interesting omission calls the Sarajevo story into question.

This omission is found on the Albanian side, where far less discussions of Fehmiu's career are readily available. In Abaz Hoxha's 2002 encyclopedia of Albanian film, a careful and detailed compilation of biographical sketches of virtually all figures of this national film tradition, be they directors, actors, screenwriters, composers, or technicians, a lengthy entry on Fehmiu argues that the actor was born in 1932 rather than 1936, and fails to mention a place of birth. This is one of the few instances in Hoxha's work in which this detail is eliminated. Hoxha simply alludes to Fehmiu's studies in Belgrade, work with the national theatre in Priština, and international career. Why might such contradictions or omissions be of interest? Was it essential that Fehmiu be Yugoslav born to promote the myth of national unity? Was this myth further reinforced by transporting the actor's place of birth from Albania to Sarajevo to further downplay ties to Albania or to Illyrian culture at large? In any case, both the former Yugoslavia and Albania lay claim to actor, the latter, albeit, cautiously.

\section{An Albanian Rubirosa}

Alexander Petrović's 1967 I Even Met Happy Gypsies (Skupljaci perja) is the film that introduced Fehmiu to the West. In this work, which was highly acclaimed in Western Europe, Fehmiu plays a charismatic gypsy who, cramped by his claustrophobic family life, rescues and runs off with a young girl who has been sold into marriage with a twelve-year-old boy. The gypsy eventually kills his lover's evil stepfather, and the lovers are forced to flee from the law. Of particular consequence is that the film was shot in Romany. (It was subtitled even in Yugoslavia). Moreover, it incorporated a number of Romani songs, one of which would later become 
the recognized national anthem of the Roma. Through this film, Fehmiu became immediately recognized as exotic, charismatic, and rugged. Gilbert's film would draw upon these three characteristics to create its hero, albeit placing him in a very different social setting.

The Adventurers relates the tale of a young man growing up in a revolution-plagued Latin American country. Marked by the murder and rape of his mother and sister, he nonetheless deploys his animal magnetism and legendary virility to rise to fame and notoriety in Europe. The protagonist's name, Dax Xenos, is highly evocative. Denoting "stranger" or "foreigner" in Greek, Xenos textualizes something exotic or "non-Latin" in the hero (despite Gilbert's insistence that the protagonist look Latin American). In this way, the name distinguishes the character markedly from prototype Rubirosa. More specifically, "Xenos," by virtue of its "Greekness," recalls the Balkans, albeit in the broadest sense defined by Iordanova. This further inscribes Fehmiu into a discourse of the exotic as I Even Met Happy Gypsies had done a few years earlier.

Young Dax, who has landed in Rome with his diplomat father, soon embarks on a life of excess and opulence, enjoying fast cars and faster women. Following his father's death in a political murder, the hero involves himself in the politics of his homeland and becomes for a short time an unwitting pawn of the dictatorship. But this does not daunt him. Marrying a wealthy heiress (Candice Bergen), the playboy joins the jet set and fornicates his way through Europe, New York, and the Bahamas. Among his conquests are an acclaimed opera singer (Anna Moffo), loosely modelled on Maria Callas, and the wife of a Texas billionaire (Olivia de Havilland). Through the meddling of a former boarding school buddy, a closet homosexual, Dax's attempt to do good (for once!) by importing tractors to his native Corteguay becomes an arms deal to support the military junta, which is striving to squelch a burgeoning revolutionary front. Despite the blunder, Corteguay is liberated, and Dax is briefly united with a childhood sweetheart (Leigh Taylor-Young) and introduced to their love child, appropriately named "Che." (His lover, the daughter of the country's dictator, immediately recalls Flor de Oro Trujillo, whose marriage to Rubirosa facilitated the latter's climb to fortune.) But the playboy is not destined for true love or fatherhood; rather, he is gunned down by a sniper. Dax's death is indeed romanticized. Like Schiller's Joan of Arc, who dies in battle rather than at the stake, the hero is taken out by a political assassination instead of a Ferrari. Unlike Rubirosa, who died in Paris, Gilbert's hero meets his death in his liberated homeland. It is significant to note a major political reversal; although Dax's father supports the dictatorship, and the hero, moreover, loves the caudillo's daughter, he eventually redeems himself through a nod to revolution in a way that was unconceivable for Rubirosa.

The casting of Bekim Fehmiu in The Adventurers sets into motion a complex dynamic in which race and ethnicity converge. Although the actor's distinct look may be deemed "exotic," it nonetheless conveys "whiteness," in contrast to the indigenous or African appearance of so much of the population of countries bearing marked similarities to the fictional Corteguay. Dax Xenos's whiteness implies an elitist dynamic in which the hero can blend in seamlessly with the children of émigré Russian aristocrats and American heiresses. Yet Fehmiu's European-ness is hard to place. His Illyrian features and Albanian accent are not immediately recognized by most viewers. He functions as a prototype of the European-European in features and style, yet transcending the specifics of an easily recognizable nationality. Indeed he imbues xenos, but such strangeness is uncannily familiar.

Fehmiu, however, was not always prototypically "European" during his international career. On occasion, his own background and education were more closely textualized in the narratives. One year following The Adventurers, he starred in Burt Kennedy's spaghetti-western The Deserter. Concerned about the actor's accent, Kennedy confronted Fehmiu during shooting regarding apparent problems with his character, a cavalryman now in the Old West. Fehmiu himself devised a back story for the character, making him a native of Belgrade whose family had immigrated to the US in 1842 and who had lost his parents two years later to cholera, a tragedy which prompted him to run off with the cavalry. In a May, 2001 interview with Sanja Domazet of Danas, Fehmiu stresses that the decision to make the character Serbian and from Belgrade was in homage to his drama teacher and all of the actors of the Yugoslav National Theatre. International audiences, unaccustomed to the marked difference between a Serbian and an Albanian accent, would be deaf to subtleties, and the choice squelched Fehmiu's Albanian ethnicity in favour of his adopted home, Belgrade. (Such a choice was in direct contradiction to advice the actor had received from a Minister in Tito's government, who recommended that he always be known as an Albanian) (Lekić15). In his autobiography, moreover, Fehmiu expands upon his friendship with a drama teacher knowledgeable of Albanian literature 
and history who encouraged the young actor to serve as a role model for Yugoslavia's Albanian ethnicity, otherwise relegated to more marginalized places in society. Albanian at home? Yugoslav abroad? Were these the dynamics of Fehmiu's career? Perhaps until its final phases.

\section{Belgrade Reports}

In apparent contradiction to the lack of material on Albanian film, a substantial file of Serbian-language documents in the Yugoslav National Film Archives foregrounds the career of Bekim Fehmiu. These clippings indicate that Fehmiu appears to have embodied the myth of Yugoslav unity in the Tito years. Yet this embodiment has been highly questionable. Much of the ambiguity in Fehmiu's case comes from the actor's longstanding refusal to take a strong stance on national issues or to involve himself too directly in anything resembling Albanian nationalism in the arts. Particularly problematical are the ties he cautiously sought with Albania, which were sporadic and aborted. (It was relatively late in his career that Fehmiu played an ethnic Albanian on the screen.)

In a 1982 interview with Jasmina Lekić published in Intervju (probably the most elucidative interview with Fehmiu), the actor appears to stress his own cautious position vis-à-vis nationalism and the problems which would ultimately lead to the 1998-99 war in Kosovo. When asked about issues of Albanian identity, Fehmiu stresses that national discourse has tended to over-emphasize rifts between Albanians and Serbs, while ignoring commonalities. Regarding the question of an independent Kosovo, Fehmiu skirts the issue and focuses instead on a discussion of the freedoms guaranteed by the (then) Yugoslav constitution, thereby supporting by implication the notion of Yugoslav unity. In a like manner, Fehmiu refuses to answer directly as to how he, an Albanian in Belgrade, feels about the situation in Kosovo. Instead, he asks the converse question: how does someone in Belgrade feel about his Albanian ethnicity? (15) He continues by indicting social issues rather than ethnic problems for the prevailing malaise in Yugoslavia. Fehmiu describes his first visit to Albania, an occasion allegedly intended to secure his agreement to star in an epic on the life of Albanian national hero, Skanderbeg. The actor stresses that he accepted the proposition, but that nothing further was pursued by the Albanian side.

Countering claims that it is difficult to think of the actor as a real Albanian, Fehmiu recalls a 1967 reception at Tito's estate in which a governmental minister counselled the actor that he should always emphasize his Albanian ethnicity. Fehmiu questioned, "why"? If he were to emphasize that he were an Albanian from Kosovo, it would appear in the eyes of those "who don't see further from their nose," a sign of nationalism. To this effect, Fehmiu mentions a New York City reception in 1968, a publicity event in which, despite Paramount's fashion advice, he opted to wear an Albanian national costume. He emphasizes that The New York Post questioned the costume choice, focusing on Fehmiu's clothing over other issues. The actor relates such a concern to the widespread, anti-Yugoslav propaganda regarding the oppression of Albanians. In defence of Tito's Yugoslavia, Fehmiu stresses that the sporting of national costumes was most accepted and popular. The actor fails to conflate such celebratory dress with a discourse of heightened nationalism. Once again, one senses a deep investment on Fehmiu's part in the myth of Yugoslav multiculturalism. The interview concludes as the actor asserts that he is teaching his sons Albanian, not for reason of nationalism, but rather, as his father used to say, "the more languages you know, the more you are worth." (15)

Some nineteen years later, in the aforementioned interview with Sanja Domazet, Fehmiu addresses in part ethnic dynamics. Breaking a fourteen-year silence and speaking of his career, ethnic violence in the region, and his own precarious position between Albanian and Serbian cultures, Fehmiu relates anecdotes from personal experience as an ethnic Albanian whose career blossomed in Belgrade. The actor describes the ethnic atmosphere which ultimately led to his retirement, an atmosphere which contrasted sharply with that of the early days of his career. Although Fehmiu strongly indicts Serbian prejudice in the interview, he implicates both sides in the perpetuation of tension; the coexistence of Slavic and Illyrian cultures has been anything but symbiotic. Overtly stated in the interview is Fehmiu's passionate love for the Serbian nation. Married for many years to Serbian actress Branca Petrić, the actor has in fact raised his children bilingually. Fehmiu once again speaks of his Serbian drama teacher who was very familiar with Albanian literature and history and encouraged him to pursue a theatrical career. Such positive experiences with Serbs rendered the war in Kosovo even more painful. To this effect, the actor issues a startling statement:

For me history is really a teacher of life. The way Hitler started with Jews, I was from the start 
aware that it started with Albanians, but that it would not end with them. I knew the war was coming. The worst fate finally struck the Serb nation. Again, we had the situation in which a Serb shoots at another Serb. I think that nothing worse can happen to a nation.

The significance of these remarks is that Fehmiu, in the Danas interview, addresses first and foremost the Serbian people, and does so from within, not from outside of the community. Fehmiu's undisputable identification with Serbia has been seen on other occasions over the course of his career, particularly in his decision to make his character and ethnic Serb in The Deserter.

\section{Tirana Retorts}

Considerably distinct from the articles found in the Yugoslav press is the Albanian perspective on Fehmiu, his nationality, and career. On the occasion of the actor's 1972 visit in April to Albania, filmmaker Vitori Ceeli made a nine-minute, $35 \mathrm{~mm}$ newsreel focusing on the importance of the visit. Çeli, an Albanian born in New York in 1928, had studied film dubbing in Moscow before assuming a position as editor at Tirana's nascent Kinostudio. By the mid-sixties, Çeli had come into his own as a documentarist (Hoxha 2002). The newsreel, titled Bekim Fehmiu në Shqipëri (Bekim Fehmiu in Albania) consists of silent footage of Fehmiu's Albanian visit with a plush score and a female voice-over which describes the otherwise obvious images. The film shows Fehmiu's arrival in Tirana and his meeting with film directors Todi Bozo, Viktor Gjika, Piro Milkani, Endri Keko, etc. It follows the actor as he visits the castle of Albanian national hero Gjergj Kastrioti (more commonly known as Scanderbeg) in Krujes and the historical museum there. (We must recall that Fehmiu was invited to Albania with the intent of starring in a film based on the life of Scanderbeg. As the actor has asserted, upon his arrival there, there was little evidence that such a production was realistically underway or even planned.) Other visits documented in Çeli's film include the archeological and war museums in Durrës, the ancient ruins of Butrint, and the port of Luani, one of the legendary harbors of Homer's Odyssey. Textualizing the actor's commitment both to his craft and to Marxism, the film shows both a meeting between Fehmiu and fellow thespians as well as an obligatory stop in which he contemplates the grandeur of the Mao Zedong hydroelectric plant in Vau i Dejes. Throughout the film, Fehmiu is presented as sexy and trendy (sporting the typical over-the-ear haircut and tight trousers of the period). Moreover, his mood seems always upbeat and cordial. Ceeli evokes a notion of pan-Albanianism and a sense of fraternity with a compatriot from outside of national territory. One of the most intriguing sequences of the film was obviously the result of the director's expertise in editing and his knowledge of Soviet cinema. By inter-cutting shots of Fehmiu at a May Day parade in Tirana and of Comrade Enver Hoxha waving to crowds, the film creates the illusion that Fehmiu personally met Albania's chief of state.

Of particular consequence is a sequence shot in Shkodër, where Fehmiu visits his childhood home. The voice-over identifies the house as the actor's birthplace. Once again, the issue of Fehmiu's actual place of birth is clouded. Although there is no doubt that the actor's family was born in Albania and that he spent several years in Shkodër as a small child, this seems not to have been enough. One of the primary missions of Çeli's film was to lay claim to Fehmiu, making him Albanian to offset the official Yugoslav story of his Sarajevo birth. In its celebration of pan-Albanian brotherhood, Bekim Fehmiu in Albania downplays the actor's Belgrade education, involvement in the Serbian theatre, and marriage to an ethnic Serb.

Poet and screenwriter Natasha Lako sheds a less optimistic light on the relationship between Fehmiu and Albania. Unlike Çeli's documentary, she frames Fehmiu within the broader context of ethnic strife. Inasmuch as Albanians were cognizant of the actor's close ties with Serbian culture and language and with the cultural mechanism of the former Yugoslavia, they treated Fehmiu with a certain distance and caution. This was heightened by Fehmiu's recitation of a folk verse, which stressed that Albania's women work while its men rest (Lako 2004). It is important to note that, despite Fehmiu's work in numerous national cinemas, he never appeared either in Albania per se either on stage or in film. He would have to work for Italian television in order to play an Albanian.

\section{The Best of Actors, the Worst of Actors}

The Adventurers was indeed the most publicized of Fehmiu's efforts in the West. In Maynard Frank Wolfe's 1970 photo essay, The Making of "The Adventurers," an interview with Lewis Gilbert attests to the director's relationship with Fehmiu. According to Gilbert, the first priority following the finalization of the script was the casting of the hero, Dax Xenos. "The physical requirements were that he look Latin American and yet 
still be able to carry off the role of an international figure. I wanted someone about thirty years old who was fantastic but who was also unknown" (34). Gilbert initially learned of Fehmiu from his wife, who had read a profile in Elle in which the star of I Even Met Happy Gypsies was described as a cross between Belmondo and Brando. (It is significant to note that Fehmiu's performance in the Yugoslavian film engendered similar reactions in the United States; Renata Adler of the New York Times foregrounded the actor's resemblance to Belmondo at the time of the opening of I Even Met Happy Gypsies.)

Upon the urging of his family, Gilbert approached Dino De Laurentiis, who had used the actor in an Italian television series. The director recalls the "animal peasant quality" he detected in Fehmiu (35) and speaks of the actor's immediate determination to learn English for the role. Fehmiu, Gilbert recounts that Fehmiu spent mornings with a teacher, afternoons at acting school, and evenings at the theatre during a three month period in England. Yet it is clear from Gilbert's words that, in his mind, Fehmiu was a Yugoslav, and only a Yugoslav. No mention is made in the Gilbert interview or elsewhere in Wolfe's book regarding the actor's Albanian nationality.

In the United States, the reviews of The Adventurers were scathing. Following an advance premiere in March, 1970, Canby argues that "no amount of cutting or editing [was] going to change the film for the better." He asserts: "In The Adventurers, when a character swears he will eventually kill another (as happens in two different plot developments), you know he will - which may be primitive melodrama, but it is also comforting, as it reassures the audience that there are still movies being made where clichés can be trusted." Referring to Gilbert's actors, Canby describes "an all-star cast composed mostly of people who've either had it or who have not yet made it." He stresses:

The acting is uniformly terrible, but not really unbearable because it also seems to be as ingenuous as the mind that originally conceived the characters. Bekim Fehmiu, a young Yugoslav actor who looks like an especially rumpled Ben Gazzarra, plays Dax, the Rubirosa-type hero. Says one of his mistresses: "You don't make love to girls. You make love at them"-which is pretty much the way he acts.

Howard Thompson further berates Fehmiu's acting by arguing:

The question is not so much why as how Mr. Fehmiu, referred to by others as a man among men, merely looks at women meltingly and they succumb (in a few unstartling peeks at bare anatomy), which is how he hooks Miss Bergen who performs as though clubbed over the head. The dialogue simply may have stunned her (May 26 1970).

Only a year later, Thompson writes a favourable critique of Fehmiu's work. Reviewing The Deserter, Thompson states that "it is hard to believe that Bekim Fehmiu, having survived a marshmallow blob titled The Adventurers, is excellent as the deserter, toughest and meanest of the pack." No mention, however, is made of Fehmiu's ethnicity. The US publicity simply refuses to acknowledge that the actor is Albanian, although his Yugoslav nationality is evoked on numerous occasions. How different things might have been had the actor debuted in the US at the time of the war in Kosovo!

\section{My Way or the Highway}

Although Fehmiu had been cast in the sixties and seventies as "vaguely Balkan" or as Greek, in the 1974 The Adventures of Ulysses, 1983 marked a major turning point for the ethnic dynamics of his international career. He was cast as an Albanian for the first time in film, playing Mother Teresa's father in Brunello Rondi's The Voice (La vocazione di Suor Teresa, 1982), on the childhood and youth of Mother Teresa of Calcutta. It is noteworthy that he played an Albanian in Italy rather than in Albania or in the Albanian diaspora. ${ }^{(2)}$

Although alleging retirement, the actor did, on one occasion, consider collaborating with Albania. Contacted by director Kujtim Çashku for the lead role in Colonel Bunker, a 1996 film relating the grim story of a colonel selected to spearhead the 1968 campaign of bunkerization, a defence strategy which would stretch well into the mid-1980s, Fehmiu expressed initial interest in the project. Negotiations between Fehmiu and Çashku, however, brought to light clear differences in artistic vision. While the director sought to explore the psychological impact of the paranoia of the Hoxha regime on the individual in a Kafkaesque fashion, Fehmiu was locked into the mindset of the superhero. He was unwilling to accept the psychological splintering and 
deterioration of the character. The role was eventually given to Agim Qirjaqi, and Çashku's film enjoyed a high level of critical acclaim internationally. To this date, Fehmiu remains in indirect contact with the film world through his brother, whom he has empowered to respond on his behalf to inquiries (Çashku).

\section{Reading Fehmiu, Reading the National}

Any theoretical explanation for the contradictory dynamics of Fehmiu's national affinities and of his place in national iconographies must take into account theories of nation. We must recall Karl W. Deutsch's early remarks on the national discourse. Deutsch writes: "The essential aspect of the unity of a people...is the complementarity or relative efficiency of communication among individuals" - something that is in some ways similar to mutual rapport, but on a larger scale (1966: 188, emphasis added by Schlesinger).

In his discussion of Deutsch, Philip Schlesinger reminds us that Deutsch sees a people "as providing the basis for the forging of a nationality [a process distinct from] nation-statehood, where political sovereignty is harnessed to the pursuit of a group's cohesion and the continuity of its identity" (Schlesinger 19-20). Schlesinger reminds us that a key implication of such theories is that communicative practices of nationalities set up communicative barriers, causing marked gaps in the efficiency of communication with others (Schlesinger 20, cites Deutsch). Recalling Benedict Anderson's privileging of language as a vehicle for establishing a common discourse (Schlesinger 28), Schlesinger suggests the importance of language in cinematic nation building.

Language is indeed a factor leading to the underwriting of national identity on Fehmiu's career in distinct ways in the Yugoslav, Albanian, and international contexts. For Yugoslavia of the sixties and seventies, Fehmiu's fluency in Serbian and use of that language as a creative tool attest to the well-touted unity and good will among the nation's peoples. For Albania, it was the actor's native command of the national language that allowed him entry, albeit cautious and partial, into dialogue with the Albanian artistic community. Although nothing concrete on a professional level materialized from this dialogue, Fehmiu would not have been courted for roles had he not been an Albanian speaker. In the West, Fehmiu's difficult-to-pin-down, yet decidedly European accent allowed him to function both prototypically and exotically. (Even when the actor was cast as an ethnic Serb in The Deserter, his accent was decidedly non-Serbian and unrecognizable to most Westerners.

But one must not be quick to oversimplify the dynamics of language in Fehmiu's case. Fehmiu was bilingual, and bilingualism opens doors to other paradigms of identity. Yet these dynamics can be extremely subtle. In fact, Serbian became Fehmiu's language of professional discourse. And it was from this national (Yugoslav) public discourse that the actor was able to progress to an international career, at least in the days in which a Yugoslavian passport was the most welcome of all of the Communist states in the West. And in Tito's discourse of unity, Yugoslavia was not an imagined community, rather, an imagined community of communities.

Although significant at home, Fehmiu's Albanian ethnicity was meaningless abroad; few in the West understood the importance of Albanian culture in Yugoslavia. It was when ethnic tensions rose to new heights that the paradigm shifted. Fehmiu haltingly textualized his Albanian nationality on the international screen, all the while finding himself more clearly at the centre of a local cultural, religious, and linguistic whirlwind. And the actor's response reflected the contradictions and disjunctures of the time.

He became much more fervent in his open denouncement of Serbian anti-Albanianism and a more vocal defender of his own ethnicity, at the same time publishing his memoirs in Serbian and underscoring his love for ethnic Serbs and the cultural dynamics of Belgrade as a capital. Despite this fervour, Fehmiu's approach thus has remained one of caution, of a double cultural indemnity which attempted to satisfy both communities. But this approach became more difficult once the imagined community of communities had shattered. Ethnic dynamics forced Fehmiu to abandon acting. He now commutes between Belgrade and Priština. Fehmiu remains in retirement, and the Balkans remain the Balkans.

(The author gratefully acknowledges the generous assistance of Natasha Lako, Kujtim Çashku, Borislav Stanojović, and Vanja Ludović in the preparation of this manuscript. He further acknowledges the support of Elgün Karimov, whose vision and encouragement have been essential to the completion of this work.) 


\section{Notes}

1. The Southern Serbian province with ninety percent Albanian population which has been under United Nations administration since 1999 [ed. note].

2. Ironically, Mother Teresa is another Albanian jointly claimed by Yugoslavia and Albania. Born in 1910 in Skopje, Macedonia, the nun's family actually took up residence in Tirana. Tirana, moreover, recently renamed its airport Mother Teresa International.

\section{References}

Adler, Renata. "Yugoslavia's I Even Met Happy Gypsies. New York Times 21 March 1968, p. 57.

Anderson, Benedict. Imagined Communities: Reflections on the Origin and Spread of Nationalism. London: Verso, 1991.

"Bekim (Kao Ruburoza) zena je krho bice koje tres a osvajati." Film Novosti 9 October, 1968, 7-10.

Canby, Vincent. "Can 'Bombs' Still Make Money?" New York Times 8 March 70: 11.

Çashku, Kujtim. Personal contact. 20 May 2005.

Deutsch, Karl W. Nationalism and Social Communication: An Inquiry into the Foundations of Nationalism. Cambridge, MA: MIT UP, 1966.

Domazet, Sanja. "We Have Crossed All Borders that Must Not Be Crossed. Interview with Bekim Fehmiu." Danas 21 April to 2 May 2001. Online on the website of the Albanian Canadian League Information Service, http://www.albca.com/aclis/modules.php?name=News\&file=article\&sid=301. Accessed 22 June 2006.

Durham, Edith. Twenty Years of Balkan Tangle. London: G. Allen and Unwin, 1920.

Hoxha, Abaz. Enciklopedi e kinematrografisë shqiptare. Tiranë: Botimet Toena, 2002.

Iordanova, Dina. Cinema of Flames: Balkan Film, Culture and the Media. London: British Film Institute, 2001.

Emir Kusturica. London: British Film Institute, 2002.

Lako, Natasha. Personal contact, March 15, 2004.

Lane, Rose Wilder. The Peaks of Shala. New York: Harper and brothers, 1923.

Lekić, Jasmina. "Bekim Fehmiu: Dogadjaji na Kosovu mene nisu iznenadili." Intervju 29.10.1982, pp. 12-15.

Schlesinger, Philip. "The Sociological Scope of 'National Cinema'” In Hjort, Mette and Scott Mackenzie. Cinema and Nation, 19-31.

Thompson, Howard. "The Adventurers." New York Times 26 May 1970: 58.

"It's About Blimps." New York Times 1 April 1977: C 10.

Wolfe, Maynard Frank. The Making of "The Adventurers." New York: Paperback Library: 1970.

Žižek, Slavoj. The Metasases of Enjoyment. London: Verso, 1994.

\section{Author Information}

Bruce WILLIAMS is Associate Professor and Chair of the Department of Languages and Cultures of the William Paterson University of New Jersey. His research includes European and Latin American avantgarde cinemas, nation and sexuality in narrative cinema, and the interrelationship between film and minority languages. His articles have appeared in Film History, The Quarterly Review of Film and Video, Post Script and The Canadian Journal of Film Studies. 